\title{
Potential International
} Litigation in the Context of Transboundary Pollution: With Special References to the Disposal of Radioactive Water into the Ocean by Japan

\author{
Jinyup Kim*
}

Since the Japanese government recently unveiled a plan to release radioactive water into the ocean, the neighbouring countries have expressed concerns. In particular, certain environmental groups claimed that the execution of this operation would have a significant impact on the marine environment in the region. In light of significant potential risks, this article argues that such an operation is likely to trigger an international dispute at an international court or tribunal for several reasons. Accordingly, this article would like to explore the highly likely international litigation. First, the background of this potential international litigation, including the reasons why the operation may end up at an international court or tribunal are addressed. Subsequently, certain legal and factual issues that are expected to be contested between the parties at the court or tribunal are discussed. Finally, this article discusses some of the expected outcomes of this likely international litigation, including reparation.

\section{Keywords}

Radioactive Water, State Responsibility, UNCLOS, Transboundary Pollution, International Litigation

* Lecturer of law at Myongji University, Seoul, Korea. LL.M. (Edinburgh), Ph.D. (Glasgow). ORCID: https://orcid. org/0000-0001-7319-7041. The author may be contacted at: kjy3751@gmail.com/Address: 34 Geobukgol-ro, Seodaemun-gu, Seoul 03674 Korea.

All the websites cited in this article were last visited on September 10, 2021. 


\section{Introduction}

In March 2011, a great earthquake, followed by a tsunami, struck a nuclear plant in Fukushima, leading to the partial meltdown of the plant's three nuclear reactors. Since then, the Japanese government has been struggling to cope with numerous problems such as nuclear waste. It has particularly been haunted by the question of how it should deal with the water that was contaminated by radioactive particles. For a decade after the accident, this radioactive water has been stored in massive tanks primarily because certain radioactive particles could not be removed through the clean-up process. As the water used to keep the reactors cool has been piling up, however, the site of these tanks containing the water is expected to exceed capacity within the next two years. ${ }^{1}$

In April 2021, the Japanese government and the plant operator-the Tokyo Electric Power Company (TEPCO)-finally announced that they would release the contaminated water into the ocean in a couple of years due to the shortage of tank storage space. ${ }^{2}$ Both the government and TEPCO claim that the [contaminated] water will not pose much risk to the environment and human health because most hazardous substances will be removed in the clean-up process; even those few that are left will not pose any danger-a claim that is supported by some countries and organizations (e.g. US and the International Atomic Energy Agency). ${ }^{3}$ However, Japan's neighbouring countries-particularly South Korea and China-have expressed serious concerns about the safety of the operation and certain environmental groupssuch as Greenpeace-argue that even after the clean-up process the water still contains radioactive substances that will cause significant damage to the marine environment in the region. ${ }^{4}$

Such conflicting views have triggered a dispute between the countries concerning the planned operation. This article argues that the dispute could lead the countries in the region to international litigation due to the difficulties in bridging the gap

1 B. Lynn, Fukushima to Run Out of Water Storage by 2022, VOA News, Aug. 15, 2019, https://learningenglish. voanews.com/a/fukushima-to-run-out-of-water-storage-by-2022/5040140.html.

2 L. Craft, Protests as Japan says it will dump radioactive water from crippled Fukushima nuclear plant into the Pacific, CBS NEws, Apr. 13, 2021, https://www.cbsnews.com/news/japan-fukushima-radioactive-wastewater-nuclear-plantpacific-ocean-protest. This plan was reaffirmed by Japan's new prime minister Fumio Kishida in October 2021. See J. McCurry, Fukushima: Japan's new PM won't delay release of contaminated water into ocean, GuARDIAN, Oct. 18, 2021, https://www.theguardian.com/world/2021/oct/18/fukushima-japans-new-pm-wont-delay-release-ofcontaminated-water-into-ocean.

3 Id.

4 Id. 
between the two sides and the compulsory jurisdiction under the United Nations Convention on the Law of the Sea (UNCLOS). Consequently, this article explores the highly likely (or potential) dispute between the involved countries at an international court or tribunal.

To that end, Part II of this article will discuss the background of the potential international litigation. In Part III, a number of legal and factual issues surrounding the potential litigation will be addressed, such as the prescription of provisional measures, the appreciation of evidence and the substantive and procedural obligations in international law. That is, the discussion will examine: to what extent provisional measures could be prescribed; whether the evidence presented by the (potential) injured states can be admitted to the tribunal or court; and what international law obligations can be disputed. Finally, Part IV will deal with some of the expected outcomes of the international litigation, including reparation.

\section{Background of the Potential International Litigation}

\section{A. Conflicting Views}

When the Fukushima nuclear power plant was hit by an earthquake that was followed by a tsunami on March 11, 2011, some of the plant's reactors were damaged. This led to their partial meltdown primarily because the reactors' cooling systems failed. ${ }^{5}$ In order to stop the meltdown of the reactors and fuel, the plant workers flooded the reactors with seawater. ${ }^{6}$ A few days later, TEPCO decided to release some of the contaminated water, with a lower level of radioactivity, into the ocean because more space was needed to hold the more highly radioactive water that had been used to keep the reactors cool. ${ }^{7}$ Since intentional releases, the contaminated water has been stored in massive tanks at the site. Nonetheless, a number of radioactive water leaks have been discovered, ${ }^{8}$ and some of these leaks had even gone unreported

5 Hiroko Tabuchi \& M. Wald, Japanese Scramble to Avert Meltdowns as Nuclear Crisis Deepens After Quake, N.Y. TIMES, Mar. 12, 2011, https://www.nytimes.com/2011/03/13/world/asia/13nuclear.html.

6 A. Kingdon, Fukushima's Radioactive Wastewater Dilemma, HAKAI MAG., Nov. 26, 2020, https://www.hakaimagazine. com/article-short/fukushima-radioactive-wastewater-dilemma.

7 Japan nuclear plant releases radioactive water into sea, BBC NEws, Apr. 4, 2011, https://www.bbc.com/news/ world-asia-pacific-12954664.

8 Hiroko Tabuchi \& M. Fackler, More Radioactive Water Leaks at Japanese Plant, N.Y. Times, Dec. 4, 2011, https:// www.nytimes.com/2011/12/05/world/asia/more-leaks-from-fukushima-daiichi-nuclear-plant.html. See also Mari Saito \& Antoni Slodkowski, Japan says Fukushima leak worse than thought, government joins clean-up, ReUTERs, Aug. 8, 
for months, which indicates that TEPCO struggled to come to grips with them. ${ }^{9}$ Despite such uncertainty and risks, Japan's Nuclear Regulation Agency launched a campaign to promote dumping the contaminated water into the ocean, arguing that it is a responsible and safe operation even though this radioactive water reportedly contains certain harmful radioactive particles, including tritium. ${ }^{10}$

Following the above described struggles and problems encountered during the past decade, the Japanese government finally made an announcement in April 2021 that TEPCO would dump the radioactive water into the ocean in two years, mainly due to the lack of storage space. ${ }^{11}$ The Japanese government and TEPCO have since continued to argue that this operation will be safe and not pose any significant threats to the marine environment and public health. More specifically, they argue that most radioactive elements in the contaminated water will be reduced to safe levels during the clean-up process (called the Advanced Liquid Processing System: ALPS), except for isotope tritium. They consider it to be a safer option than other alternatives, such as evaporating the water, ${ }^{12}$ and insist that tritium be relatively harmless and many nuclear power plants around the world have been releasing water containing tritium into the ocean. ${ }^{13}$ In addition, the Japanese environmental minister has claimed that releasing the radioactive water into the ocean is the only (viable) option, stressing that there are no other available options. ${ }^{14}$

However, this plan has received much criticism from some experts, environmental groups and neighbouring countries. First, although most of the radioactive substances will be removed during the clean-up process and only a few substances such as tritium would remain, other hazardous radioactive substances, including carbon-14,

2013, https://www.reuters.com/article/us-japan-fukushima-pm-idUSBRE97601K20130808.

9 Radioactive Fukushima Water Leak Was Unreported for Months: Official, NBC News, Feb. 25, 2015, https://www. nbcnews.com/news/world/radioactive-fukushima-water-leak-was-unreported-months-official-n312396.

10 K. Mathiesen, Is it safe to dump Fukushima waste into the sea? Guardian, Apr. 13, 2016, https://www.theguardian. com/environment/2016/apr/13/is-it-safe-to-dump-fukushima-waste-into-the-sea.

11 J. McCurry, Fukushima: Japan announces it will dump contaminated water into sea, GuARDIAN, Apr. 13, 2021, https:// www.theguardian.com/environment/2021/apr/13/fukushima-japan-to-start-dumping-contaminated-water-pacificocean.

12 T. Schauenberg, Fukushima: How the ocean became a dumping ground for radioactive waste, DeUTSCHE WeLLE, Mar. 11, 2020, https://www.dw.com/en/fukushima-how-the-ocean-became-a-dumping-ground-for-radioactive-waste/ a-52710277.

13 Yuka Obayashi \& Kaori Kaneko, Japan to release Fukushima's contaminated water into sea: reports, ReuTERs, Oct. 16, 2020, https://www.reuters.com/article/us-japan-disaster-water/japan-to-release-fukushimas-contaminated-waterinto-sea-reports-idUSKBN27037O.

14 Yoko Wakatsuki, Japan may have to dump radioactive Fukushima water into the ocean because it's out of storage space, CNN, Sept. 10, 2019, https://edition.cnn.com/2019/09/10/asia/japan-environment-minister-fukushima-waterhnk-intl/index.html. 
cannot be removed. ${ }^{15}$ While claiming that the treated water in the tanks contained only tritium, in 2018 and 2020, TEPCO finally admitted that the water still contained contaminants other than tritium, such as carbon- $14{ }^{16}$ which is a radioactive isotope that can damage human DNA. ${ }^{17}$ This confirms that the Japanese government and TEPCO still struggle to clearly identify the substances in the water. ${ }^{18}$

Furthermore, despite the argument that ocean release is the only (viable) option, other available options have been studied by an advisory panel in Japan and approved by the IAEA. The IAEA particularly stresses that two out of the initial five options-namely, "controlled discharge into the sea" and "controlled vapor release"are technically feasible. ${ }^{19}$ Nevertheless, the Japanese government continues to insist on the ocean release option, probably due to its lower cost, according to some critics. ${ }^{20}$ This is most likely because, prior to the earthquake and tsunami, TEPCO ignored the findings of its own internal studies, which suggested that the plant might be vulnerable to a large tsunami and that a protective barrier is needed. The primary reason for ignoring these findings was probably the high cost of building such a barrier at the expense of safety. ${ }^{21}$

Moreover, the Japanese government and TEPCO downplayed and slowly admitted relevant incidents, such as radioactive water leaks over the last decade. That is, Japan and TEPCO were 'extremely' reluctant to admit the meltdowns of the

15 S. Denyer, A decade after Fukushima nuclear disaster, contaminated water symbolizes Japan's struggles, WASH. Post, Mar. 6, 2021, https://www.washingtonpost.com/world/asia_pacific/fukushima-japan-radioactive-wateranniversary/2021/03/05/b0515cd0-76b8-11eb-9489-8f7dacd51e75_story.html.

16 S. Burnie, Stemming the tide 2020: The reality of the Fukushima radioactive water crisis, Greenpeace Germany (Oct. 2020), at 6, https://www.greenpeace.org/static/planet4-japan-stateless/2020/10/5e303093-greenpeace stemmingthetide2020_fukushima_radioactive_water_crisis_en_final.pdf. Some media reports find that even tritium can be dangerous in large quantities because tritium's beta particles are not said to be able to penetrate human skin but are thought to build up inside the body if inhaled or consumed in large quantities. See C. Edwards, Nuclear dump: Japan running out of space for radioactive Fukushima water-and says dumping it in the OCEAN is now 'unavoidable, 'SuN, Apr. 8, 2021, https://www.thesun.co.uk/tech/14585299/japan-fukushima-radioactive-water-ocean.

17 B. Wilkins, Lethal Levels of Radiation Found in Damaged Fukushima Reactor, Impacting its Shutdown, Ecowatch, Dec. 31, 2020, https://www.ecowatch.com/fukushima-lethal-radiation-2649706408.html.

18 To understand how dangerous other substances are in the water in the tanks, see M. Penn, How the 2011 tsunami destroyed Japan's trust in nuclear power, AL JAZEERA, Mar. 10, 2021, https://www.aljazeera.com/news/2021/3/10/thecosts-of-nuclear-power-japan-fukushima.

19 See IAEA Follow-up Review of Progress Made on Management of ALPS Treated Water and the Report of the Subcommittee on Handling of ALPS Treated Water at TEPCO's Fukushima Daiichi Nuclear Power Station, Apr. 2, 2020, https://www.iaea.org/sites/default/files/20/04/review-report-020420.pdf.

20 The Ministry of Economy, Trade and Industry (METI) of Japan, The Subcommittee on Handling of the ALPS Treated Water: The Subcommittee on Handling of the ALPS Treated Water Report, (Feb. 10, 2020), at 7 (Table 2), https:// www.meti.go.jp/english/earthquake/nuclear/decommissioning/pdf/20200210_alps.pdf.

21 Supra note 14. 
three reactors during the first few weeks following the disaster ${ }^{22}$ and then proceeded to downplay and cover up additional bad news, such as radioactive water leaks. An expert maintained: "They spent eight years without telling us about it, and now they are saying: Trust us, we are going to take care of it." ${ }^{23}$

Finally, neighbouring countries are more concerned that a significant amount of "treated" water will be released over the next three decades or longer. ${ }^{24}$ It could be damaging the neighbouring areas, not only because they are close to Japan but also because these areas or seas (i.e. East Sea, Yellow Sea and East China Sea) are either nearly-enclosed basins that have very limited exchanges with open oceans or partially-enclosed basins that have moderate interactions with open oceans along one or two of their boundaries. ${ }^{25}$ One major finding by Greenpeace is that such disposal of contaminated water into the ocean can lead radioactive materials into the East Sea within a year, which would occur environmental harm shortly after disposal begins. ${ }^{26}$ Despite these concerns and risks, in response to requests from neighbouring countries for relevant information to be provided, the Japanese government continues to claim that ocean release is a matter of 'sovereignty' and refuses to provide reliable information about the water it intends to release. ${ }^{27}$

Overall, disagreements about the operation have developed, causing a dispute(s) between the countries. Whether international litigation is actually instituted or not, this article argues that the countries are likely to end up invoking state responsibility at an international court or tribunal for several reasons, which are discussed below.

\section{B. Why is State Responsibility Invoked at an International Tribunal or Court?}

In this case, "state responsibility" will be a point at issue because, while the planned operation is to be conducted by TEPCO, it is primarily controlled by the Japanese government responsible for making relevant decisions, including whether to release contaminated water into the ocean. Article 4 of the Draft Articles on Responsibility of

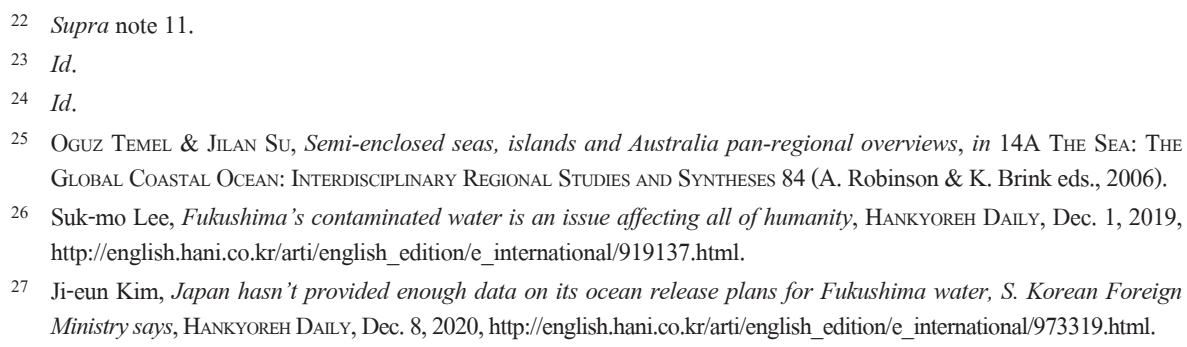


States for Internationally Wrongful Acts, with commentaries 2001 (hereinafter Draft Articles on State Responsibility), the UN International Law Commission (ILC) states that the conduct of any state organ, including an organ of the central government and a territorial unit of the state, shall be considered to be an act of the state under international law and that the organ includes any person or entity who has such status in accordance with the internal law of the state. ${ }^{28}$

Article 5 of the Draft Articles of State Responsibility further states that the conduct of a person or entity who is not an organ of the state under Article 4 but is empowered by the law of that state to exercise elements of governmental authority shall also be considered an act of the state under international law, provided that the person or entity is acting in that capacity in the specific instance. ${ }^{29}$ In particular, the second paragraph of the Article 5 commentary states that the entity reflects a wide variety of bodies, including public corporations, semi-public entities, public agencies of various kinds and even private companies, if these bodies are empowered by the law of the state to exercise functions of a public character. ${ }^{30}$ Accordingly, this article would argue that the operation to be conducted by TEPCO and controlled by the Japanese government falls within the category of conduct of the state, regardless of TEPCO's character. In the meantime, any (likely) transboundary environmental harm in the area resulting from the operation (e.g. higher than average level of radioactive waste in the seas or animals therein, as in the case of radioactive waste in the Irish $\mathrm{Sea}^{31}$ ) that would occur over wide territorial sea areas amounts to direct injury to the state(s) or state property in which case diplomatic protection and the principle of exhaustion of local remedies do not apply. ${ }^{32}$ As a result, such conduct of a 'state' that causes (likely) harm to the environment or property of "another state" can trigger an 'interstate' dispute that involves the invocation of "state responsibility."

If the potential disputing parties in the region (i.e. Japan v. South Korea and/or China) are to settle the interstate dispute that involves state responsibility deriving from (potential) transboundary environmental harm, ${ }^{33}$ the primary means for

28 ILC Draft Articles on Responsibility of States for Internationally Wrongful Acts, art. 4(1) \& (2).

29 Id. art. 5. [Emphasis added]

30 Id. art. 5, commentary 2. [Emphasis added]

31 The discharge of radioactive water from a nuclear power plant at Sellafield made the Irish Sea the most radioactively contaminated sea in the world. For details, see Cumbrians Opposed to a Radioactive Environment (CORE), http:// corecumbria.co.uk/alternative-tour-of-sellafield/irish-sea.

32 For details, see ILC, Draft Articles on Diplomatic Protection with commentaries 2006, art. 14, commentary 12. [Emphasis added]

33 As stated in the Mavrommatis Palestine Concessions case by the PCIJ and in the East Timor case by the ICJ, a dispute is a disagreement about a point of law or fact, a conflict of legal views or of interests between two persons. See The Mavrommatis Palestine Concessions (Greece v. U.K.), Judgment, 1924 P.C.I.J (ser. B) No. 3 (Aug. 30); Case 
dispute settlement under the UN Charter include negotiation, enquiry, mediation, conciliation, arbitration, judicial settlement and resort to regional agencies or arrangements. $^{34}$ These means are largely divided into two categories-namely, voluntary and compulsory ones-with the former comprising negotiation, enquiry, mediation and conciliation and the latter comprising arbitration and judicial settlement. The potential disputing parties would first be involved in negotiation because it constitutes the first step towards settling disputes between countries without the involvement of third parties. ${ }^{35}$ If they fail to find a resolution for the dispute(s) through negotiation, a third party would most likely be involved. In this case, non-judicial means, including mediation or conciliation, would be used prior to the compulsory ones.

In particular, it can be imagined that regional organizations or agencies could play a role as mediators or conciliators to settle the disputes between them, ${ }^{36}$ although binding decisions cannot be made by such regional organizations or agencies because there is no binding regional convention with an enforcement mechanism devoted to the protection of marine environment in the region. ${ }^{37}$

Although it depends on specific circumstances and the potential disputing countries in the region could resolve their dispute through the voluntary dispute settlement means mentioned above-namely, negotiation or conciliation (by regional organizations)-this article would argue that it is most likely for them to proceed with the dispute to compulsory means for the following reasons. First, as noted above, while Japan is continuously arguing that only tritium is left in the 'treated' water after the clean-up process and this radioactive substance is not harmful to the environment and human health, its neighbours and environmental groups claim that this water still contains other (ultra) hazardous substances, such as carbon-14. Second, even tritium is harmful only in bulk, the water is still being contaminated and thus dangerous. Finally, Japan insists that releasing this water be their sovereignty, rejecting its neighbours' requests to share relevant information.

In light of obstinate stance, Japan would be continuously arguing that it is doing utmost to prevent any danger by fulfilling relevant obligations. Thus, considering the (contrasting) stances and differences of involved parties over this issue, it would

35 Anthony Aust, Handbook of International Law 397 (2d ed. 2010).

36 For details, see NOWPAP, Institutional Framework: Regional Seas, https://www.unep.org/nowpap/index.php/who-weare/institutional-framework; PEMSEA, Our Organization, http:/www.pemsea.org/about-pemsea/our-organization.

37 See The MOX Plant case (Ireland v. U.K.), List of cases No. 10, Order of 13 November 2001, https://www.itlos.org/ fileadmin/itlos/documents/cases/case_no_10/published/C10-O-13_nov_01.pdf. 
be extremely hard for these countries to settle such dispute via the voluntary dispute settlement means but to resort to compulsory binding dispute settlement-namely, arbitration or judicial settlement mainly because public opinions in the potential injured states are concerned about the potential dangers posed by Japan's radioactive water ${ }^{38}$ and are making their governments unable to step back. These circumstances might possibly lead the governments to refer the dispute to an international court as a means of dealing with the political pressure from the public and/or environmental groups. ${ }^{39}$

Consequently, the international litigation would be the most plausible way to resolve this dispute. ${ }^{40}$ Unlike domestic judicial systems, however, settling a dispute in an international court or tribunal (i.e. by compulsory means) requires mutual consent. ${ }^{41}$ It means that only when both parties in a dispute agree to submit it to an international court or tribunal, the court or tribunal can have jurisdiction over it. Accordingly, even if South Korea or China wants to bring the case to an international court or tribunal, they cannot do so without the consent of Japan. That said, in this case, they will face few obstacles in filing a lawsuit against Japan in an international tribunal or court for the following reasons.

First, as discussed above, because the radioactive water pollution would occur in the 'seas,' the main applicable law would be the UNCLOS (Part XII) which addresses the protection of the marine environment. ${ }^{42}$ One of the innovative features of the UNCLOS is its compulsory dispute settlement system, according to which any dispute concerning the interpretation or application of this Convention shall, ... be submitted at the request of any party in the dispute to the court or tribunal having jurisdiction. ${ }^{43}$

The UNCLOS provides four procedures for the settlement of disputes such as the International Tribunal for the Law of the Sea (ITLOS), the International Court of Justice (ICJ), an arbitral tribunal or a special arbitral tribunal constituted in accordance with Annex VIII for one or more of the dispute categories specified therein, including protection and preservation of the marine environment. ${ }^{44}$ In particular, if the parties

38 See, e.g., Sang-myoung Lee, 92 percent of the Korean people are concerned about the danger posed by the radioactive water and even more than half of them support the boycott of the 2020 Tokyo Olympic Games [국민 92\%, 후쿠시마 원전사고 방사능 우려...절반이상 도쿄올림픽 불참 ‘찬성’], SHINAILBO DAILY, Mar. 11, 2020, https://www.shinailbo.co.kr/ news/articleView.html?idxno=1258296.

39 See, e.g., David Houghton, US Foreign Policy and the Iran Hostage Crisis 2-4 (2001).

40 For some reasons, including state immunity, it is highly unlikely for them to pursue the legal action in domestic courts. See generally Patricia Birnie et al., International Law and the Environment 304 (3d ed. 2009).

41 Supra note 35 , at 400.

42 See ITLOS, Press Release: Order in the MOX Plant Case [Ireland v. United Kingdom] at 2, https://www.itlos.org/ fileadmin/itlos/documents/press_releases_english/PR_No.62.pdf.

43 UNCLOS art. 286. [Emphasis added]

44 Id. art. 287(1) \& annex VIII, art. 1. 
in a dispute have accepted the same procedure for settling the dispute, it may be submitted only to that procedure; otherwise, it may be submitted only to arbitration in accordance with Annex VII (i.e. an arbitral tribunal). ${ }^{45}$

Based on the above provisions and the fact that all the (main) potential disputing parties including South Korea, China and Japan have ratified the UNCLOS, the potential dispute would probably be placed in one of the four procedures specified in the Convention. In fact, an arbitral tribunal, which was established under the UNCLOS in 2002, confirmed its prima facie jurisdiction in MOX Plant, ${ }^{46}$ which was a very similar case concerning the operation of a nuclear plant and subsequent (potential) radioactive waste pollution between the United Kingdom (UK) and Ireland. In that case, however, the European Court of Justice (ECJ) claimed exclusive jurisdiction and later removed the dispute from the arbitral tribunal. ${ }^{47}$ Of course, such a challenge would not apply to this potential dispute in Northeast Asia because these countries do not belong to any regional organization, such as the European Community (i.e. now, the European Union). Overall, considering the scientific, circumstantial (i.e. political and economic) and legal facts or issues, there is a possibility that the potential disputing parties will be pushed to resolve their dispute in one of the four international courts or arbitral tribunals.

\section{Factual and Legal Issues of the Potential International Litigation}

\section{A. Provisional Measures}

Provisional measures can be applied by the disputing parties and prescribed by the court or tribunal to which a dispute has been duly submitted to preserve their respective rights or prevent serious harm to the marine environment, pending the final decision. ${ }^{48}$ The measures can be prescribed, modified or revoked by the court or tribunal that the parties agreed (or if the parties do not agree on any particular tribunal or court) by the ITLOS pending the constitution of an arbitral tribunal

45 Id. art. $287(4) \&(5)$.

46 The MOX Plant case (Ireland v. U.K.), Order No.3, 24 June 2003, https://pcacases.com/web/sendAttach/867.

47 N. Lavranos, On the Need to Regulate Competing Jurisdictions between International Courts and Tribunals 18 (European University Institute Working Paper EUI MWP, 2009/14, 2009).

48 UNCLOS art. 290(1), (3). 
provided the urgency of the situation so requires. ${ }^{49}$ After the constitution of the arbitral tribunal, the tribunal can modify, revoke, or affirm the provisional measures, as noted above, in order to preserve the respective rights of the parties in the dispute or prevent serious harm to the marine environment, pending the final decision. ${ }^{50}$

In the MOX Plant case, Ireland requested provisional measures that required the UK to immediately suspend authorization for the MOX plant and to ensure that no action was taken that might prejudice the rights of Ireland. ${ }^{51}$ In response, the ITLOS found that the urgency of the situation did not require the prescription of the provisional measures, as requested by Ireland, ordering them only to exchange further information, to monitor risks or effects of the operation and to devise, as appropriate, measures to prevent the pollution of the marine environment that might result from MOX plant operation. ${ }^{52}$

In light of the specific circumstances of this dispute in Northeast Asia, given that the ITLOS interpreted urgency to encompass the need to "prevent any action likely to be taken which may cause serious harm" to the marine environment in the MOX Plant case, ${ }^{53}$ provisional measures are likely to be ordered by the court or tribunal for the protection of the marine environment despite (scientific) uncertainty in this case. That said, unless "serious harm" is highly likely or actual harm is 'serious' enough to severely degrade the marine environment and thus violate the rights of potential injured state(s), as provided in Article 290 of the UNCLOS, more measures would not be included in the provisional measure other than exchange of information and monitoring (like in the MOX Plant case). In this case, Japan could be ordered to suspend the operation pending the final decision. This would especially be the case if the request is made before the release because no country can veto the activity itself. ${ }^{54}$ Although this dispute could be resolved through provisional measures, ${ }^{55}$ the

49 Id. art. 290(5).

$50 \mathrm{Id}$.

51 ITLOS, Press Release 59: The MOX Plant Case Request for Provisional Measures Submitted by Ireland (Nov. 13, 2001), at 1-2, https://www.itlos.org/fileadmin/itlos/documents/press_releases_english/PR_No.59.pdf.

52 ITLOS, Reports of Judgements, Advisory Opinions and Orders, the Mox Plant Case, List of cases: No. 10, Provisional Measures, Order of Dec. 3, 2001, at 110-1, https://www.itlos.org/fileadmin/itlos/documents/cases/case_no_10/published/ C10-O-3_dec_01.pdf. [Emphasis added]

53 J. Harrison, Saving the Oceans through Law: The International Legal Framework for the Protection of the Marine EnVIronment 40 (2017).

54 ILC Draft Articles on Prevention of Transboundary Harm from Hazardous Activities, with commentaries 2001, art. 1, commentary 6. [Emphasis added]

55 E.g., Malaysia and Singapore came to an amicable settlement based on the provisional measures that ordered the cooperation and exchange of information between the two countries in the Case concerning land reclamation in the Johor Straits, https://www.itlos.org/fileadmin/itlos/documents/cases/case_no_12/12_order_100903_en.pdf. For details, see supra note 53 , at 67. 
differences in the views and attitudes of the countries in the region could lead the court or tribunal to proceed to hear their arguments on the merits. This would especially be the case if any (serious) damage is found in the area primarily because the issue of compensation would arise. Accordingly, this article moves on to discuss some important issues that are expected to be contested.

\section{B. Causation and the Proof of Harm}

Prior to discussing proof of causation, even if no harm is yet found, the potential injured states could submit the dispute to an international court or tribunal, not only because Article 1 of the UNCLOS contains "the introduction ... of substances or energy into the marine environment, [...] which results or is likely to result in such deleterious effects as harm to living resources and marine life" within the scope of its definition of "pollution of the marine environment," but also because its Article 194 requires states to take all measures consistent with this Convention that are necessary to prevent, reduce and control pollution of the marine environment from any source. [Emphasis added] In this case, the focus should be on the 'potential' for such harm. As noted above, such factors as the uncertainty regarding the materials contained in the water, the expected release of a massive amount of contaminated water over a very long period of time and the geological features of the areas to be affected (i.e. semi-enclosed seas) have made neighbouring countries especially concerned. A particular concern is, according to some scientific findings, that the radioactive water is expected to reach the neighbouring seas in just a couple of years after the release. ${ }^{56}$

Accordingly, even if no (serious) harm has yet been found, the potential injured parties could claim 'potential' harm on the basis of the above facts and findings. With respect to such claims, although an international court or tribunal has the discretion to decide whether such scientific findings and facts are convincing, given the (broad) definition of what constitutes pollution of the marine environment found in the UNCLOS and the stance adopted by the ITLOS in the MOX Plant case, which was premised on consideration of prudence and caution, ${ }^{57}$ the danger of such potential harm could be recognized by the court or tribunal. However, if any (serious) harm is found, it is most likely to be a higher level of radioactive substances, including ultrahazardous materials such as carbon-14, in the seas. If such environmental harm does

56 Supra note 26.

57 In the provisional measures, the Tribunal ordered the parties to, inter alia, devise measures to prevent pollution of the marine environment, as appropriate, which might result from the operation of the MOX Plant, https://www.itlos.org/ fileadmin/itlos/documents/cases/case_no_10/published/C10-O-3_dec_01.pdf. 
occur, the link between the harm and the operation of releasing the water could be contested by the parties at the court or tribunal.

When it comes to the appreciation of evidence, Professor Rüdiger Wolfrum, a former ITLOS judge, stated in his separate opinion for the M/V Saiga case between Saint Vincent and the Grenadines and Guinea that international law and international courts or tribunals have not yet provided clear guidance and have, instead, focused on developing regulations regarding procedural aspects concerning the submission of evidence by the parties. ${ }^{58}$ Emphasizing that the appreciation of evidence should be guided by principles of impartiality and fair trial, Wolfrum raised the following two important questions: (i) which of the parties has the burden of proof?; and (ii) what is the standard of appreciation to be used in assessing the evidence produced $?^{59}$ For the former, Wolfrum noted that while the burden of proof lies on "the party who asserts them" in all legal systems, international tribunals enjoy some discretion concerning the standard of proof. ${ }^{60} \mathrm{He}$ also stated that a criterion should exist against which given evidence is to be determined, according to which two standards of proof are applied: (i) proof beyond reasonable doubt that requires a high degree of cogency; and (ii) preponderance of evidence, which means that the appreciation of evidence points in a particular direction even though reasonable or even more than reasonable doubt remains. ${ }^{61}$

On this ground, the burden of proof (of damage or injury) first lies on the potential injured states (i.e. South Korea and China). Hence, they should present any evidence before the court or tribunal showing the injury caused to them through the environmental harm due to the radioactive water released by Japan (e.g., data on the higher level of radioactive substances found in the neighbouring seas). Regarding the appreciation of this evidence, while the court or tribunal has some discretion, it would probably adopt the preponderance of evidence standard primarily because it would be difficult to find other source(s) that could cause such higher radioactive substance levels in the neighbouring seas, except for a massive amount of released contaminated water, unless Japan could provide sufficient contrary evidence, such as a natural disaster triggering the explosion of a nuclear power plant in another country of the region.

\footnotetext{
58 The M/V Saiga (No. 2) Case (Saint Vincent and the Grenadines v. Guinea), Separate Opinion of Vice-President Wolfrum, 1999 ITLOS Rep. 92, (July 1999), https://www.itlos.org/fileadmin/itlos/documents/cases/case_no_2/ published/C2-J-1_Jul_99-SO_W.pdf.

59 Id. 93.

$60 \quad$ Id. 94.

61 Id.
} 
Moreover, according to the ILC, although the principle of causation is a highly discretionary branch of law, developments have moved to a less stringent causation test, requiring only the "reasonable imputation" of damage in many jurisdictions. ${ }^{62}$ Furthermore, the Seabed Disputes Chamber made it clear in its Advisory Opinion on Seabed Activities that the precautionary principle can reduce the standard of proof required to establish that an activity poses a risk of harm. ${ }^{63}$ Consequently, the evidence presented would probably be admitted to the court or tribunal as being indicative that their injury is the result of Japan's operation.

\section{Due Diligence or Standard of Care}

Once evidence is admitted to the court or tribunal, considering that, as Japan argues, the release of radioactive water is not, per se, prohibited by international law-falling within their sovereignty-and there is no strict or no-fault liability rule for states in the context of transboundary (environmental) harm, the potential disputing parties would begin contending whether or not any objective fault has occurred-namely, whether Japan violated any obligations it owes to international law, particularly with regard to "act[ing] with due diligence" before the court or tribunal. ${ }^{64}$

As noted above, the main law applicable by the court or tribunal would be Part XII of the UNCLOS. Given that: (i) not only the Convention but also other rules of international law not incompatible with it must be applied by the court or tribunal; ${ }^{65}$ (ii) many provisions on the protection of the marine environment in the Convention require states to take into account or consider "international rules and standards," albeit to varying degrees; ${ }^{66}$ and (iii) the Convention mainly purports to function as "a basic and coordinating international legal instrument" or an 'umbrella' convention, 67 this article analyses not only the relevant provisions in the Convention, but also other relevant rules of international law that provide detailed rules and standards.

\footnotetext{
62 ILC Draft Principles on the Allocation of Loss in the Case of Transboundary Harm Arising out of Hazardous Activities, art. 4, commentary 16.

63 A. Boyle, Transboundary air pollution: A tale of two paradigms, in TransBoundary Pollution: Evolving Issues of International Law and Policy 244 (R. Beckham et al. eds., 2015).

64 A. Boyle, Globalizing Environmental Liability: The Interplay of National and International Law, 17 J. ENVTL. L. 3-26 (2005). See also supra note 40, at 430.

65 UNCLOS art. 293(1). It provides: "A court or tribunal having jurisdiction under this section shall apply this Convention and other rules of international law not incompatible with this Convention." [Emphasis added]

66 A. Boyle, Marine Pollution under the Law of the Sea Convention, 79 Am. J. InT'L L. 353 (1985).

67 Supra note 53, at 20.
} 


\section{Substantive Obligations: general obligation for the preservation and protection of the marine environment}

Part XII of the UNCLOS contains provisions for the protection and preservation of the marine environment in a general and comprehensive manner. ${ }^{68}$ For instance, while Article 194(1) requires states to take all measures consistent with this Convention that are necessary to prevent, reduce and control pollution of the marine environment from any source and to use the best practicable means at their disposal for this purpose, ${ }^{69}$ its second paragraph provides that activities under each state's jurisdiction or control must be conducted so as not to cause damage by pollution to other states and their environments, ensuring that pollution arising from incidents or activities under their jurisdiction or control does not spread beyond the areas in which they exercise sovereign rights. ${ }^{70}$ In particular, with regard to pollution from land-based sources, Article 207 requires states to adopt laws and regulations to prevent, reduce and control pollution of the marine environment from land-based sources, while taking into account internationally agreed rules, standards and recommended practices and procedures. ${ }^{71}$ Article 207 is also relevant given the fact that radioactive water is stored in massive tanks on the land, so the release of this water may fall within the category of land-based sources.

These obligations are also mentioned in international environmental declarations ${ }^{72}$ as well as endorsed by international courts or tribunals. In the Pulp Mills case, for instance, the ICJ indicated that the obligation to preserve the aquatic environment and, in particular, to prevent pollution is "an obligation to act with due diligence" that "entails not only the adoption of appropriate rules and measures but also a certain level of vigilance in their enforcement and the exercise of administrative control applicable to public and private operators, such as the monitoring of activities undertaken by such operators, to safeguard the rights of the other party."73

In addition, in its Advisory Opinion on Responsibilities and obligations of States with respect to activities in the Area, the Seabed Disputes Chamber emphasized the importance of the precautionary approach as an integral part of the due diligence obligation and the obligation of states to take all measures to prevent damage that

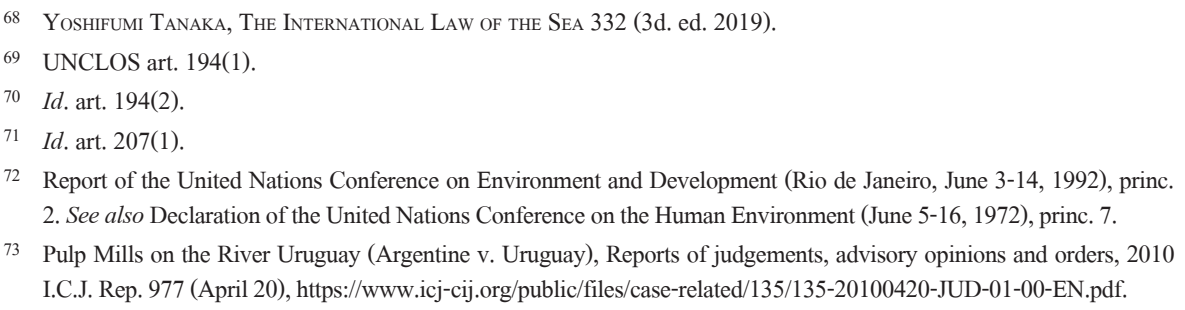


might result from activities (of contractors that they sponsor), adding that "this obligation applies in situations where scientific evidence concerning the scope and potential negative impact of the activity in question is insufficient but where there are plausible indications of potential risks." ${ }^{, 74}$ In particular, the Chamber also recognized that the "due diligence obligation" is a variable concept, stressing that it may change over time as measures considered to be sufficiently diligent at a certain moment may become not diligent enough in light of, for instance, new scientific or technological knowledge and that it may also change in relation to the risks involved in the activity. ${ }^{75}$

As noted above, the potential disputing parties would contend whether Japan violated any obligations it owed according to international law-namely, whether it acted with due diligence to prevent transboundary harm-and this would be based on the above provisions and judgements or opinions. Although it depends on circumstances, the court or tribunal could find that Japan did not act with due diligence in certain instances. For instance, if an insufficient level of vigilance is found in the enforcement of administrative control applicable to operators (e.g. TEPCO) in order to safeguard the rights of other parties, despite the adoption of measures in accordance with Articles 194(1) and 207, then this would be regarded as a failure to act with due diligence. Furthermore, if the measures adopted by Japan are considered to be insufficient in light of new scientific or technological knowledge or in relation to the risks involved in the operation, the country would then be found not to have acted with due diligence. In particular, given that the precautionary approach is of significant importance in due diligence obligation, despite the insufficient scientific evidence concerning the potential negative impact of the operation on the marine environment in the region, the (expected) level of Japan's obligation to take all measures to prevent damage that might result from the operation would be high because there are plausible indications of potential risks.

\section{Procedural Obligations: cooperation and environmental impact assessment}

In addition, some procedural aspects to discharge the due diligence obligation are also provided in the UNCLOS and other relevant rules of international law, which can be largely divided into the two categories: (i) cooperation and (ii) environmental impact assessment.

As regards the former, the UNCLOS requires states to cooperate in order to

74 Responsibilities and obligations of States with respect to activities in the Area, Advisory Opinion 131, List of cases No. 17, Feb. 1, 2011, ITLOS Rep., https:/www.itlos.org/fileadmin/itlos/documents/cases/case_no_17/17_adv_op_ 010211_en.pdf.

$75 \quad I d . \rrbracket 117$. 
formulate and elaborate international rules and standards; ${ }^{76}$ notify other states deemed likely to be affected by pollution damage, ${ }^{77}$ develop contingency plans to prevent damage; ${ }^{78}$ and encourage the exchange of information and data acquired about the pollution of marine environment. ${ }^{79}$ In particular, the Convention requires states that border an enclosed or semi-enclosed sea to cooperate in the endeavour to, inter alia, coordinate the implementation of their rights and duties with respect to the protection and preservation of the marine environment. ${ }^{80}$

The ITLOS highlights the importance of the duty to cooperate by calling it "a fundamental principle in the prevention of pollution of the marine environment under the UNCLOS and general international law" in the MOX Plant case. ${ }^{81}$ This statement was repeated by the Tribunal in the Land Reclamation by Singapore in and around the Straits of Johor case. ${ }^{82}$ In this case, the Tribunal stated that "prudence and caution require that Malaysia and Singapore establish mechanisms for exchanging information and assessing the risks or effects of land reclamation works and devising ways to deal with them in the areas concerned." 83

In addition, the ILC sets out specific contents of the duty to cooperate in its Draft Articles on Prevention of Transboundary Harm from Hazardous Activities with commentaries 2001 (hereinafter Draft Articles on Prevention of Transboundary Harm). First, Article 4 provides: "States concerned shall cooperate in good faith and, as necessary, seek the assistance of one or more competent international organizations in preventing significant transboundary harm or at any event in minimizing the risk thereof." In particular, the ILC states that cooperation extends to all phases of planning and implementation, stressing the participation of the state likely to be affected in any preventive action. ${ }^{84}$ Even though the 'necessity' to seek assistance of one or more international organizations in performing their preventive obligations was stated, such assistance from international organizations may not be necessary in every case. $^{85}$

76 UNCLOS art. 197.

77 Id. art. 198.

$78 \quad I d$. art. 199.

79 Id. art. 200.

$80 \quad$ Id. art. 123.

81 Supra note 52, $₫ 82$.

82 Case concerning land reclamation by Singapore in and around the Straits of Johor (Malay. v. Sing.), ITLOS Case No. 12, Order of Oct. 8, 2003, https://www.itlos.org/fileadmin/itlos/documents/cases/case_no_12/12_order_100903_en.pdf.

83 Id. $ๆ 99$.

84 ILC Draft Articles on Prevention of Transboundary Harm from Hazardous Activities, with commentaries 2001, art. 4, commentary 1.

85 Id. commentary 5. 
Furthermore, the ILC considers the requirement of 'notification' to be an indispensable part of any system designed to prevent transboundary harm, emphasizing that notification should be accompanied by available technical information, including raw data and information analysis. ${ }^{86}$ The ILC also states, in Article 9, the requirement of the states concerned to enter into consultation for the purpose of achieving acceptable solutions regarding measures to be adopted in order to prevent significant transboundary harm or at any event to minimize the risk thereof. ${ }^{87}$ It is especially mentioned that such consultation must be done in good faith and that the legitimate interests of states must be taken into account, which was also stated by an arbitral tribunal in the Lake Lanoux case. ${ }^{88}$ Finally, the ILC mentions that the requirement for consultation should be applied to all issues related to preventive measures. $^{89}$

With respect to environmental impact assessment, while Article 204 of the UNCLOS requires states to keep under surveillance the effects of any activities that they permit or in which they engage in order to determine whether these activities are likely to pollute the marine environment, Article 206 requires states to, as far as possible, assess the potential effects of planned activities under their jurisdiction or control when they have reasonable grounds for believing that such activities may cause substantial pollution of or significant and harmful changes to the marine environment. ${ }^{90}$

In the Pulp Mills case, the ICJ clarified this vague UNCLOS concept by holding that: “... it may now be considered a requirement under general international law [...] due diligence [...] would not be considered to have been exercised, if a party planning works liable to affect the régime of the river or the quality of its waters did not undertake an environmental impact assessment on the potential effects of such works." ${ }^{91}$ Moreover, the Court considered that an environmental impact assessment should be carried out prior to the implementation of a project and continuous monitoring of its effects on the environment shall be undertaken throughout the life of the project. ${ }^{92}$ Furthermore, in its Advisory Opinion, the Seabed Disputes Chamber affirmed that the obligation to carry out an environmental impact assessment is

86 Id. art. 8, commentaries $2 \& 6$.

87 Id. art. 9.

88 Lake Lanoux case (Fr. v. Spain), 12 R.I.A.A. 281, 24, 101 (Arbitral Tribunal, 1957).

89 ILC Draft articles on Prevention of Transboundary Harm from Hazardous Activities, with commentaries 2001, art. 9, commentary 8.

90 UNCLOS art. 204(2) \& art. 206.

91 Supra note $73, \llbracket 204$.

92 Id. $\mid 205$. 
a general obligation under both the UNCLOS and customary international law. ${ }^{93}$ Finally, the ILC provides for the obligation to conduct an environmental impact assessment in Article 7 of the Draft Articles on Prevention of Transboundary Harm, particularly stressing that the assessment should contain an evaluation of the possible transboundary harmful impact of the activity and that the states likely to be affected need to know the possible harmful effects that the activity might have on them. ${ }^{94}$

Based on the provisions, judgements and opinions presented above-even though it is again dependent on circumstances - some instances would be found by the court or tribunal that Japan has failed to fulfil its procedural obligations. For instance, if the potential injured states cannot participate in all preventive actions, if notification regarding (potential) pollution damage by Japan is not accompanied by available technical information, or if consultation is not conducted in good faith and fails to take into account other parties' legitimate interests, this would be then regarded as failing to cooperate properly. It is particularly likely given the current uncooperative attitude of Japan. In addition, if the states likely to be affected are not properly informed about the possible harmful effects found in an environmental impact assessment, Japan cannot argue that it acted with due diligence because the duty to carry out an environmental impact assessment is a general obligation under the UNCLOS and customary international law.

\section{Expected Outcomes of the Potential International Litigation}

Although various orders or judgements could be made by a court or tribunal, this article will explore the most likely verdict(s) based on several cases. Actually, there are some instances in which Japan could be found to have failed to act with due diligence. In such case(s), since it is the obligation "of conduct," not "of result," some legal consequences of internationally wrongful conduct would be addressed by the court or tribunal. Hence, this article discusses some of the main possible legal consequences: (i) cessation of the wrongful act; (ii) performing the obligation breached; and (iii) reparation.

Even if Japan is not found guilty of failing to act with due diligence, since the

93 Supra note $74, \boldsymbol{\Upsilon} 145$.

94 ILC Draft Articles on Prevention of Transboundary Harm from Hazardous Activities, with commentaries 2001, art. 7, commentaries $7 \& 8$. 
operation will occur over a long period of time, the court or tribunal is likely to order the parties to take all necessary measures for the preservation and protection of the marine environment in the region and to find an acceptable solution through negotiation. In the Gabcikovo-Nagymaros Project case, the ICJ ordered the parties to negotiate in good faith in light of the prevailing situation and to establish a joint operational regime for the dam (instead of terminating the activity). ${ }^{95}$ Among the measures that can be taken by the parties, the "liability and compensation rules concerning nuclear damage to their marine environment" shall be focused on for the parties because such a liability and compensation agreement (at bilateral, trilateral or regional level) that stipulates the rights and duties of the parties including non-state entities could contribute not only to mitigating the concerns of the potential injured states, but also to preventing further or future damage. In fact, Article 235(3) of the UNCLOS requires states to cooperate in the further development of international law in relation to responsibility and liability for the assessment of and compensation for damage and the settlement of related disputes, as well as, where appropriate, for the development of criteria and procedures for the payment of adequate compensation, such as compulsory insurance or compensation funds. Hence, this article will discuss how to develop such liability and compensation rules by suggesting key elements that should be contained in the rules (or agreement).

\section{A. Cessation of Wrongful Conduct and Performing the Breached Obligation}

Once a breach is found of the international legal obligation to act with due diligence, the legal consequences for an internationally wrongful act would arise.

First, a responsible state would be required to perform the breached obligation, to cease the wrongful conduct, and to offer appropriate assurances and guarantees of non-repetition if circumstances so require. ${ }^{96}$ Accordingly, Japan would be required to cease any wrongful act (e.g., insufficient enforcement of laws and regulations or not providing available technical information upon notification) and to perform the obligation to act with due diligence by consulting the other parties in good faith and taking into account their legitimate interests. In addition, given that the operation is planned to take place for the next few decades, appropriate assurances and guarantees of non-repetition of such violation should be accompanied by, say,

95 Gabcikovo-Nagymaros Project (Hung. v. Slovk.), Judgement, 1997 I.C.J. Rep. 692, 155 (Sept. 25), https://www. icj-cij.org/public/files/case-related/92/092-19970925-JUD-01-00-EN.pdf.

96 Supra note 28 , arts. $29 \& 30$. 
devising mechanisms for exchange of information and participation in any preventive actions.

\section{B. Reparation: Restitution, Compensation and Satisfaction}

Japan would be under an obligation to make full reparations for injuries caused by its internationally wrongful act. The ILC provides three forms of reparation: (i) restitution, (ii) compensation, and (iii) satisfaction. ${ }^{97}$

If no actual harm is found but only the potential for harm, the main means of reparation would most likely be satisfaction, which could take such forms as an acknowledgement of the breach, an expression of regret, or a formal apology, ${ }^{98}$ along with the fulfilment of the breached obligations.

However, if any harm or damage is found, restitution and/or compensation would come into play. ${ }^{99}$ With regard to restitution, the ILC requires the responsible state to re-establish the situation that existed prior to the wrongful act being committed, provided that such restitution is materially possible and does not involve a burden that is out of proportion to the benefit deriving from restitution instead of compensation. ${ }^{100}$ The ILC adopts an even narrower definition-the re-establishment of the situation that existed prior to the occurrence of the wrongful act, not a broader one that requires the (re)establishment of the situation that would have existed if the wrongful act had not been committed. ${ }^{101}$ In this potential dispute, the most likely harm would take the form of an increased level of radioactive particles within vast sea areas. Considering that it is (almost) materially impossible to restore seas back to the past within a short period of time or that, at least, such restoration would involve a burden that is out of proportion to the benefit deriving from restitution instead of compensation, the parties should resort to compensation.

In its Draft Articles on State Responsibility, the ILC requires the state responsible for an internationally wrongful act to compensate for damage caused, providing that the compensation shall cover any "financially assessable damage," including loss of profits. ${ }^{102}$ Furthermore, the ILC addresses the actual losses incurred as a result of the internationally wrongful act to constitute the main function of compensation and

\footnotetext{
97 Id. art. 34.

98 Id. art. 37(2).

99 See ILC Draft principles on the allocation of loss in the case of transboundary harm arising out of hazardous activities, with commentaries 2006, princ. 2, commentary $2 \& 3$.

100 Supra note 28, art. 35.

101 Id. commentary 2. [Emphasis added]

102 Id. art. 36(1) \& (2).
} 
recognizes monetary payment to be a general form of compensation. ${ }^{103}$ In addition, the Commission mentions that financially assessable damage encompasses both damage suffered by the state itself, including its property, and damage suffered by its nationals. ${ }^{104}$ In particular, the ILC emphasizes that payments have been offered for expenses that are reasonably incurred in preventing or remedying pollution or, to provide compensation for a reduction in the value of polluted property in some cases. ${ }^{105}$ In the Trail Smelter case, for instance, compensation was provided to the US for land and property damage caused by sulphur dioxide emissions from a smelter across the border in Canada, which was assessed on the basis of the reduction in value of the affected land. ${ }^{106}$

Based on these discussions, in the potential dispute discussed in this article, compensation would probably take the form of monetary payment that covers any financially assessable damage in the seas and it can be calculated on the reduction in value of the affected seas as in the Trail Smelter case. Such compensation would include the damage suffered by the affected state(s), as well as damage suffered by their nationals.

\section{Liability and Compensation Rules to Prevent Further or Future Damage: Key Components of the Potential Agreement}

\section{Basic Principle: imposing strict liability on operators, not states}

As noted above, there is no strict (or no-fault) liability rule for states in international law in the context of transboundary pollution. ${ }^{107}$ In practice, however, strict liability has a number of advantages for preventing and addressing transboundary pollution. First, imposing 'strict' liability on a certain entity to compensate for the (transboundary) damage can provide ex ante incentives to invest in disaster (or pollution) mitigation, particularly in the context of man-made disasters, which is the basic starting point of the economic approach to law. ${ }^{108}$ In particular, if there are multiple entities, strict liability could push a bigger risk contributor(s) to make more

\footnotetext{
103 Id. commentary 4.

104 Id. commentary 5.

105 Id. commentary 15.

106 Id.

107 See Pemmaraju Sreenivasa Rao, First report on the legal regime for allocation of loss in case of transboundary harm arising out of hazardous activities, ๆ 22 (Special Rapporteur), https://legal.un.org/ilc/documentation/english/a_cn4_531. pdf.

108 M. Faure, In the Aftermath of the Disaster: Liability and Compensation Mechanisms as Tools to Reduce Disaster Risks, 52 STAN. J. INT'L L. 101 (2016).
} 
efforts to mitigate the risk by relating risk contribution to financial consequences. ${ }^{109}$

Despite these advantages, it is 'exceptional' for states to be held accountable without showing any fault. Instead, most international conventions (especially in the fields of oil pollution and nuclear accidents) have focused on civil liability (of ship owners or operators of nuclear installations). ${ }^{110}$ This alternative approach has shown some advantages. First, it allows victims to directly complain about or sue the enterprise causing the damage, which facilitates the implementation of the "polluter pays" principle. ${ }^{111}$ Moreover, the implementation of this approach could contribute to internalizing the costs related to the clean-up of contaminated resources. ${ }^{112}$ Hence, the parties in the region should adopt the potential agreement concerning liability and compensation rules in relation to nuclear damage to their marine environment based on "strict liability of operators" because of the advantages stated above. Key components of this agreement are as follows. ${ }^{113}$

\section{Definition of Compensable Damage}

First, the definition or scope of compensable damage should be clarified. While some international conventions (e.g., the Convention on Third Party Liability in the Field of Nuclear Energy of July 29, 1960, or Paris Convention) limit the scope to "damage to or loss of life of any person/any property," "114 other conventions (e.g. Protocol to amend the Paris Convention) extend the scope to include "the costs of environmental reinstatement measures which are actually taken or to be taken." ${ }^{\text {"15 }}$ As noted above, the most likely harm-the focus of this potential agreement-is the damage to the marine environment in the region and, accordingly, the potential agreement should not only cover the (economic) loss arising from loss of or damage to life and property, but also the costs of the impaired environment reinstatement measures.

\section{Scope of Liability}

Most of the international conventions that contain liability and compensation rules

109 Id. at 102 .

110 Boyle, supra note 63, at 3-4. (e.g., 1960 Paris Convention on Third Party Liability in the Field of Nuclear Energy [in force in 1968]; 1971 Brussels Convention Related to Civil Liability in the Field of Maritime Carriage of Nuclear Material [in force in 1975]; 1971 Convention on the Establishment of an International Fund for Compensation for Oil Pollution Damage [in force in 1978, replaced by the 1992 Convention, in force in 1996]).

111 Id. at 3 \& 8 .

112 B. Mamlyuk, Analyzing the Polluter Pays Principle through Law and Economics, 18 S.E. EnvtL. L.J. 50 (2010).

113 Jing Liu \& M. Faure, Compensation for nuclear damage: A comparison among the international regime, Japan and China, 16 International Environmental Agreements: Politics, Law and Economics 172 (J. Gupta ed., 2016).

114 Convention on Third Party Liability in the Field of Nuclear Energy of 29 July 1960 or Paris Convention, art. 3(a).

115 Protocol to Amend the Convention on Third Party Liability in the Field of Nuclear Energy of 29 July 1960, art. 1(B). 
adopt strict liability of operators. In his seminal article, Professor Michael Faure conducted a comprehensive analysis of a number of liability and compensation mechanisms in many international conventions and found that many of the major international (environmental) conventions in diverse fields (i.e. nuclear liability, marine oil pollution and carriage of hazardous and noxious substances by sea) adopt strict liability of operators. ${ }^{116}$ As noted above, imposing strict (or no-fault) liability on the operator(s) to compensate for the (transboundary) damage they cause can provide ex ante incentives for them to invest in pollution mitigation. Therefore, a model of strict liability of operators should be adopted in the potential agreement in the region.

\section{Liable Parties}

Although numerous international conventions channel liability to the operator, the scope of operators differs. For instance, based on his analysis, Faure found that marine pollution conventions only include ship owners, while aviation conventions make not only the operator or air carrier liable, but also others entities. ${ }^{117}$ In this case, TEPCO is the main operator that conducts nuclear activities in Japan, including releasing radioactive water into the ocean. Although the potential agreement can hold only the main operator liable, other actors (e.g. facility designers) also need to be liable primarily because this would ensure that the costs (of impaired environment reinstatement measures) would spread to multiple actors, which could prevent insolvency of the main operator.

\section{Compensation}

Key components of compensation rules for damage are as follows. First, many international conventions set financial limits of compensation for operators, partly to prevent the insolvency of operators. ${ }^{118}$ However, such financial caps have been under criticism because operators are only incentivized to prevent an accident up to the amount of the limited liability, which serves to reduce prevention

\footnotetext{
116 Some of these conventions are as follows: the above-given Paris Convention; the Vienna Convention on Civil Liability for Nuclear Damage; the Protocol to Amend the Vienna Convention on Civil Liability for Nuclear Damage and the Protocol to Amend the Convention on Third Party Liability in the Field of Nuclear Energy (nuclear liability); the Convention on Civil Liability for Oil Pollution Damage and the International Convention on the Establishment of an International Fund for Compensation for Oil Pollution Damage (marine oil pollution); and the Hazardous and Noxious Substances Convention (the carriage of hazardous and noxious substances by sea). See supra note 108, at 117-22.

117 Supra note 108 , at 123 .

118 See, e.g., Paris Convention on Third Party Liability in the Field of Nuclear Energy, art. 7(b); International Convention on Civil Liability for oil pollution damage, art. 5(1); and International Convention on Liability and Compensation for Damage in Connection with the Carriage of Hazardous and Noxious Substances by Sea 2010, art. 9.
} 
incentives. ${ }^{119}$ Accordingly, if the financial cap is to be introduced for operators in the agreement, the limit should be set high enough to actually prevent the problem (i.e. reduced prevention incentives), especially considering that, when compensation is capped, victims could remain uncompensated. ${ }^{120}$ If the financial cap is set high, however, two additional problems could arise-insolvency of operators and less compensation to victims as a result of extensive damage. If the operator(s) cannot cover the (full) expenses, then the insolvency problem could occur despite the high financial cap. Consequently, many international conventions put "compulsory solvency guarantees" in place by imposing a duty to purchase financial coverage (e.g. compulsory liability insurance) for disasters. ${ }^{121}$ Accordingly, such mandatory financial security provisions should also be introduced into the potential agreement.

Last but not least, in some instances, victims could remain uncompensated due to extensive damage despite the high financial cap. To prevent such a problem, some international conventions have additional funds as extra compensation layers. For instance, the Convention of 31 January 1963 OECD Legal Instruments Supplementary to the Paris Convention of 29 July 1960 (or the Brussels Supplementary Convention) provides three layers of compensation mechanisms: (i) the operator's insurance or financial security; (ii) the contracting state; and (iii) the contracting parties. ${ }^{122}$ Similarly, the potential agreement in the region should also establish such compensation funds, as provided in Article 235(3) of the UNCLOS, in order to prevent victims from being uncompensated for damage.

\section{Conclusion}

This article has explored a potential (or highly likely) international litigation in the context of transboundary pollution resulting from the disposal of radioactive water into the ocean by Japan (particularly, into the seas in Northeast Asia). The announcement of the planned disposal of radioactive water into the ocean by the Japanese government and the resulting complaints of neighbouring countries have

119 Supra note 108 , at 124.

120 Id.

121 Id. at 109. See, e.g., Paris Convention on Third Party Liability in the Field of Nuclear Energy, art. 10; International Convention on Civil Liability for oil pollution damage, art. 7.

122 Convention of 31 January 1963 OECD Legal Instruments Supplementary to the Paris Convention of 29 July 1960 (Brussels Supplementary Convention), art. 3(b). 
generated disagreement and dispute over the planned operation. The dispute could end up at an international court or tribunal primarily because of the different stances and views of the two disputing sides and compulsory jurisdiction under the UNCLOS. Consequently, this article has discussed a number of factual and legal issues that are expected to be either be addressed or contended at the litigation such as the prescription of provisional measures, the causation and proof of harm, and the due diligence obligations based on some provisions under the UNCLOS and relevant judgements. Based on the discussion, this article has also addressed certain potential or expected outcomes including legal consequences of internationally wrongful conduct like reparation and what the key components of a potential liability and compensation agreement between the potential disputing parties would be.

The main topic of this articles centres on a 'potential' international litigation. It means that such a lawsuit might not actually happen. Nonetheless, in this article, many reasons for such a litigation have been examined presuming that it is (highly) likely to occur. Ultimately, even if it does not occur, it is truly worth discussing the factual and legal issues that can be expected to be addressed at such a litigation, as well as the liability and compensation rules, because this discussion can help identify the rights and duties of the countries in the region to transboundary pollution. In addition, the key components of liability and compensation rules identified here can be used as an instrument to prevent damage to the marine environment in the region.

Last but not least, even though this article has focused only on some countries in Northeast Asia because of the factual (scientific findings and geological features) and legal (Article 123 of the UNCLOS) contexts, the possibility that other countries could also take action against the contaminated water releasing operation should not be ruled out because most of the provisions concerning the preservation and protection of the marine environment in UNCLOS are considered customary international law. 